\title{
SPLIT LEVEL HORIZONTAL HOUSE PLAN IN THE BALKAN VERNACULAR ARCHITECTURE
}

A $B$ S $T$ T R A C

Analysing traditional residential architecture in the Balkan region, we notice a widespread use of a split level horizontal house plan. The paper studies and presents examples found in Greece, Macedonia, Bulgaria, Serbia, Montenegro, Bosnia and Herzegovina and Croatia. Based on spatial, functional and structural analysis of the house plans, depending on the reasons for the horizontal floor level split and the types of its implementation, there are different groups of buildings. One group features a structural floor level split in order to match the line of the terrain; because of the implemented floor structure; or because of a bay window or a projection construction on the façade. In the other group of buildings the reasons are of a functional nature rooted in climate, social or religious sphere. Here the floor level difference is achieved by applying secondary construction elements and certain interior details. Having conducted the analysis, we can conclude that the implementation of various horizontal floor plan level in traditional, vernacular architecture is quite significant and inspirational for the modern design process in residential houses. It shows how dynamism and complexity can be achieved in a simple way, without any partitions, giving a picturesque effect of a basic interior space. 


\section{INTRODUCTION}

Analysis of a number of traditional residential architectural examples showed a widespread use of a split level horizontal house plan, which the subject of the paper. The difference in the floor levels is mostly characteristic to residential structures. The analysis comprises characteristic examples of traditional housing in the Balkans, covering Greece, Macedonia, Bulgaria, Serbia, Bosnia and Herzegovina, Montenegro and Croatia. ${ }^{1}$ The aim of the horizontal floor plan split level analysis of the selected examples of vernacular architecture is to show the spatial and design values and possibilities of implementation in a modern design process.

The paper features a method of descriptive and functional analysis of the characteristic examples. First of all, a descriptive analysis of the selected examples was conducted and then an arrangement and functionality analysis of various horizontal floor plan split level examples. Also, analysis of a particular place and role of the split level plan (and a cross-section where needed) is done, and the examples are then classified according to the give criteria. Based on that, the causality in the horizontal plan arrangement is analysed and conclusions stated about the implementation of the split level floor plan in a process of modern architectural designing.

IMPLEMENTATION OF THE SPLIT LEVEL HORIZONTAL FLOOR PLAN IN THE BALKAN TRADITIONAL ARCHITECTURE CHARACTERISTIC EXAMPLES

For better classification, characteristic examples are given according to their geographical position, looking from east to west, regardless of their size, structure, implemented materials or horizontal plan complexity.

1. One of the oldest and simplest forms of dwellings made of stone is kuman (bunya) from the island of $\mathrm{Crete}^{2}$ (Fig. 1) with an archetypic circular plan. This one room house "avoids" angular joints with its ancient manner of building, and is of south-west orientation, with one entrance that is also an exit, a window and a chimney. The only amenity in this ascetic dwelling place is an elevated area for repose and a split level floor that follows the land slope. Similar forms of such simple houses built in rocky areas can be traced along the southern coast of the Mediterranean, all the way to Dinaric massif in the Adriatic backs. 
2. A modest house in Astypalaia, on the island of the same name in the Aegean Sea, Greece ${ }^{3}$ (Fig. 2) features two things. One is a hillside form, with the sheered ground floor following the sloping, where only the absence of a hearth indicates that it is a living or repose room. The other is an elevated section for repose on both floors, called sofa. ${ }^{4}$ This interior split level floor sometimes is high enough for storage purposes, partitioned with a wooden panel and several lavishly decorated doors.

3. A villa in Makrinitsa, near Volos in Thessaly $^{5}$ (Fig. 3), with its complex structure and size represents a social status and wealth of the owner, an eminent taxer. It is also an example of luxury architecture in the late 19th century Thessaly. On top of the two stone floors, the third one spreads freely, becomes more dynamic in its plan and shape owing to its wood-frame structure. Here we have several horizontal floor plan splits. In the central hall there is an elevated bench along the window line, providing a view of the exterior area. Above the staircase is a flat area, usually meant for repose, quite a common feature in many of the analysed plans. The central space, a hall between the rooms, features two floor level splits in a form of a niche with large windows looking at the street, with one of them projecting into an oriel window with an additional split level meant as sitting place by the window. On the opposite side there is another hall in the corner of the house, projecting on two sides, like oriel windows, and in front of which is a split area with a water pump (on the plan to the left, behind the staircase). In this way we have a highly dynamic flow in the interior hall area, with a series of horizontal splits, semi-partitioned areas, but with very few actual partitions in this unified house space.

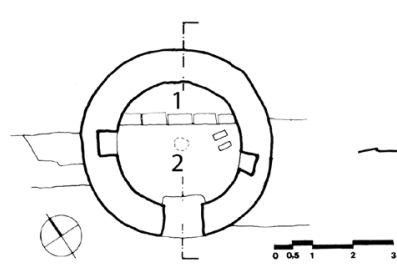

a)

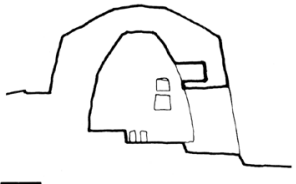

b)

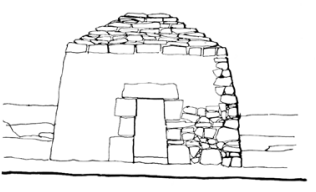

c)

Figure 1. Kuman, the basic dwelling place made of stone, the island of Crete (a. plan, b. cross-section and c. appearance)
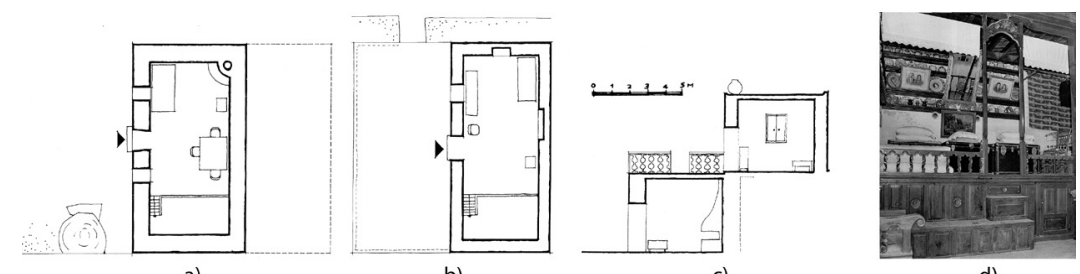

Figure 2. A freestanding house in Astypalaia, on the Greek island of the same name (a. ground floor, $b$. first floor, c. cross-section and d. sofa) 
4. A house in Teteven, Bulgaria ${ }^{6}$ (Fig. 4) features two types of horizontal floor level splits. One horizontal level split is made in the central room (2) used for cooking and dining. The split level was made because of a need for separating the hearth area from the other room space. The other split is made to elevate, in the same room, the place for repose, a bench (odar), with a storage place for grain under it (hambar). There is also a horizontal floor split on a gallery - the chardak (čardak) that serves as a connection for the rooms in the house, which also features an elevated section meant for sitting and resting (8) - a corner covered balcony (ćoška). ${ }^{7}$

5. A house in a village of Smiljan, Bulgaria ${ }^{8}$ (Fig. 5) features a number of horizontal floor level splits. It starts with a very small level split on the ground floor, just a few steps at the entrance to a semi-closed porch that serves as a central hall, which emphasises it both in function and visually. Then, each entrance to any of the rooms - those with fireplaces (2) is elevated with a separate two-side staircase with a landing, as well as at the entrance to a bathroom (3). On the first floor there are horizontal splits in each room at their entrances, immediately at the entrance (2, top left and right) or outside the entrance (2, bottom right). On the first floor, as part of the central hall area, there are several horizontal level splits made by wooden planks of the closed chardak.

Outside the entrance area for an ancillary room, klet, (3), a small room (4), there is small area with a horizontal split. Inside the small room, the horizontal splits are made in a form of benches meant for sitting along the room walls. A room that is locally called peyka (5) serves for accepting guests and is elevated and emphasised on the side façade as a projection with windows on its sides. An especially interesting feature is a large bench above the staircase, with two access steps.

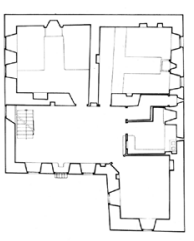

a)

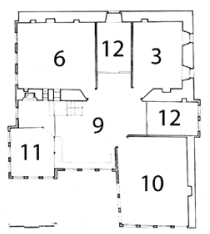

b)

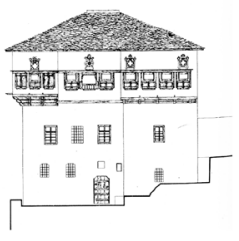

c)

Figure 3. A villa in Makrinitsa, Thessaly, Greece (a. first floor, b. second floor and c. appearance)

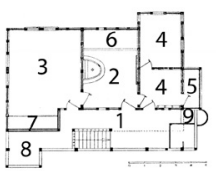

a)

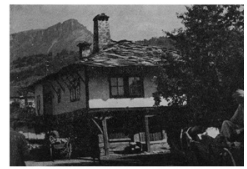

b)

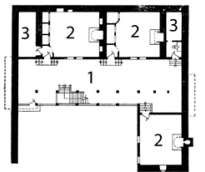

a)

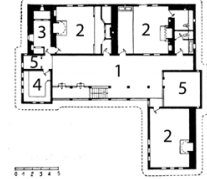

b)

Figure 4. A house in Teteven, Bulgaria (a. floor plan - 2 kuća and 8 a small covered balcony, and b. façade)

Figure 5. A house in Smiljan, Bulgaria (a. ground floor, b. first floor - 2. a room, 3 storage, 4 a small room and 5 peyka, and c. appearance) 
In this house, the rooms are separate functional units, furnished with inbuilt closets and fireplaces, and separate bathrooms, toilets, sinks and tubs. With its nicely differentiated semi-covered living areas, this house is ranked among the best examples of the 19th century traditional architecture and the highest achievements of vernacular architecture in the Balkan region.

6. A house with two galleries (chardak) in $\mathrm{Kruševo}^{9}$ (Fig. 6) is an important example of the vast Macedonian traditional architectural treasure. On the ground floor the difference in the level split is just a few steps in the main household room, and it is made as an adaptation to the sloping terrain. On the first floor there are two level splits. One is at the access to the open central hall at the entrance to the largest room with a fireplace, while the other separates the gallery area into two functional ones - the side elevated area meant for sitting and repose is locally called minsofa. The gallery is also on two levels, one being the minsofa, and the other, an elevated one above the stairs, made as a bed, is locally called a gallery porch (трою).

An anonymous builder provided a rational, functional, intelligent and very modern space, regardless of the means he applied.

7. The other house with a gallery (chardak), which is of much more modest form, in Debar, Macedonia ${ }^{10}$ (Fig. 7) has only two guest rooms on the first floor, but the area of the gallery is finely differentiated into even nine different levels, with each bearing a different name depending on the purpose (bed, orasan, šemisan, etc.) It is a veritable small textbook of a split level floor practical for everyday life, showing that the quality of a space arrangement does not necessarily depend on the complexity of a building programme or the available resources.

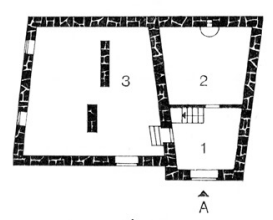

a)

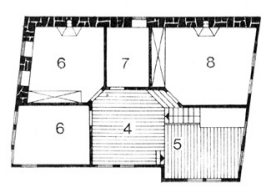

b)

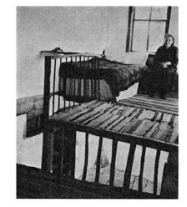

c)

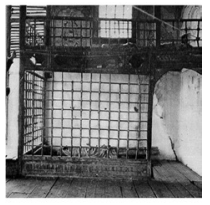

d)

Figure 6. A house in Kruševo, Macedonia (a. ground floor, b. first floor - 4 a gallery, chardak, and 5 minsofa, c. gallery detail and d. fence detail)

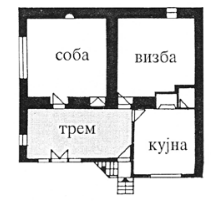

a)

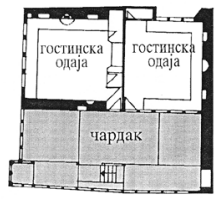

b)

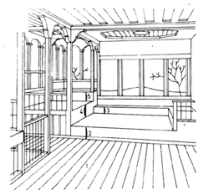

Figure 7. A house in Debar, south-western Macedonia (a. ground floor, b. first floor and c. a gallery chardak) 
8. There is an illustrative example in Vardar Macedonia, a Muslim house in Ohrid $^{11}$ (Fig. 8). This ground floor house features seven different split levels in its plan. Such nuances in splitting the horizontal plan cancel the conventional understanding of physical differences between the individual storeys connected only with staircases. In combining of those "transitional levels", the vernacular builder achieves high standards in the quality of life, sending a universal message of how space can be adapted to basic human activities (climbing the stairs, sitting, lying down, walking, etc.)

9. The house in Gusinje, characteristic for the mountainous regions of Montenegro $^{12}$ (Fig. 9) features three different ways of how the horizontal level was split. The first is in the fireplace area in the kitchen, with an elevation around it in an irregular line. At first glance it seems unnatural, but it is actually quite natural and easy to move around within the room from the larder to the projecting toilet. The second way of split level is in the rooms: under the windows there are elevated benches (minderluk), and at the elevated entrance, there is an inbuilt closet (dolap) and bathroom (a small hammam). The most interesting detail of the horizontal level split is a fine work at the stairs in the central hall where in a very small space there are the stairs, a slightly elevated landing and a projecting area for ablution, a significant Muslim housing element. The artistic effect on the façade is obvious.

10. A specific form of a traditional house in the mountainous regions is a solid stone tower (so colled - kula type) in Rožaje, Montenegro ${ }^{13}$ (Fig. 10). On its top level, built of wood, like a log cabin, there are four types of horizontal level split. The first level difference is in the kitchen, where half of the

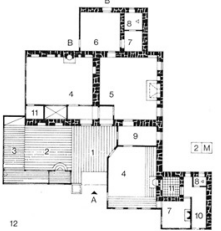

a)

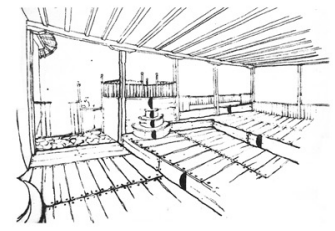

b)

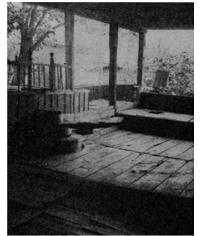

c)

Figure 8. A house in Ohrid, Macedonia (a. plan, b. covered balcony split floor level, and c. a detail)

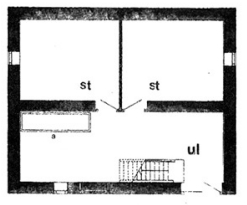

a)

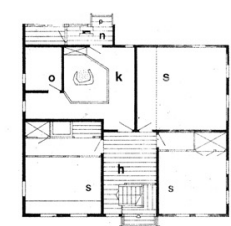

b)

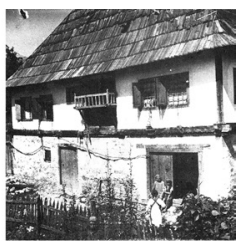

c)

Figure 9. A house in Gusinje, Montenegro (a. ground floor, b. first floor - (k) a kitchen, (h) a hall, and b. appearance) 
entire area is elevated in front of the fireplace (5), the second difference is in another room, in the section meant for personal hygiene (2 and 3). At the corner in the hall there is an elevated area added (1), projected outside the façade surface. There is a level split in the side projection in the hall that serves as a sink for washing hands (4). The shape and the arrangement of the house indicate its mediaeval origin, while all the furnishings point to Muslim and ethnic affiliation.

11. A one-storey house of Protić, in Peć, southern Serbia ${ }^{14}$ (Fig. 11), features multiple level splits on both levels. At the entrance into the house ground floor from the courtyard there is a couple of steps. The ancillary rooms, for farming purposes (6), feature various directions of split levels, caused by the sloping terrain: a room to the left from the entrance has an elevated floor, as the terrain is somewhat higher there, while the room on the right follows a slope with a lower floor level. The first floor of the house, with a cruciform hall ${ }^{15}$, the level splits go as follows: at a small covered balcony (ćoška), projecting in a shape of an oriel window with three sides (3) and in the area with water (4), both across the hall. A few steps go to an elevated larger covered balcony, also projected, overhanging the courtyard, supported with two columns, forming a deck above the entrance. Also, the two rooms (5) are entirely on different levels, with thresholds at the cut corners. A special feature in the rooms are split levels below the windows, with sitting benches; as well as at a water heating fixture and a washing place (a room in the bottom left corner), which even today makes it a high housing standard. The kitchen (6) has its level split with four steps and an additional split for the fireplace. So, this house has nicely arranged space, featuring discreet split levels all over the horizontal plan. Such a house is one of the best examples of the Balkan Peninsula vernacular architecture.

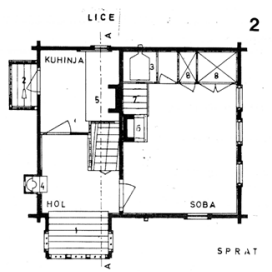

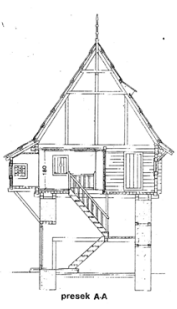

Figure 10 . Fortified dwelling place - a tower (kula type) in Rožaje, Montenegro(a. floor plan - (5) a hearth,

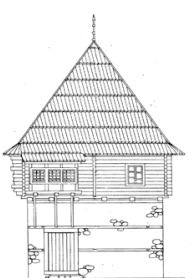
(2 and 3) bathroom, (4) a fixture for washing hands, b. cross-section and c. appearance )
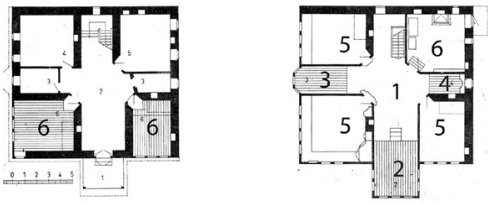

Figure 11. The Protić's house, Peć, Serbia (a. ground floor - 6 storage, b. first floor - (1) a hall, (2 and 3 )

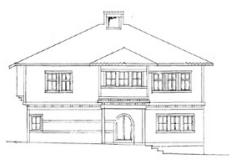
covered small balconies, (4) a place with water, (5) a room, (6) a kitchen, and c. façade) 
12. A completely different example is a house in the Ljig area, western Serbia ${ }^{16}$ (Fig. 12). As a result of a basic two-part house concept characteristic to the spacious Dinara region at the backs of the Adriatic Coast, this house was built with a timber frame, wattle and daub structure, with a somewhat reduced programme - the main room - the "house" with a hearth, two opposite placed doors, two rooms, a smaller one and a bigger one, with split levels at thresholds - doors at about $20 \mathrm{~cm}$ higher than the main room floor. The reason for this split level is found in its structure. The "house" (kuća) is on the ground level, while the rooms are above the cellar made of stone blocks, so the difference in the split level corresponds to the thickness of a beam of the wooden floor construction. In this way, a direct contact between the primary construction elements, the wooden beams, and the earth base is avoided, so split level is applied to keep the house free from damp, which actually separates the two rooms from the central one with a hearth.

13. A stone house over a cellar from Nevesinje, south-eastern Bosnia and Herzegovina $^{17}$ (Fig. 13) is of a somewhat reduced structure, built in the Herzegovina rocky and mountainous area. It is a two-part dwelling place. The manner of building shows that an anonymous builder knew how to adapt to the natural terrain, turning the slope to his advantage by applying the split level system in one of the rooms, below which is the cellar.

14. A nice leisure house in the country, in a village of Rahić, near Brčko, the northern Bosnia and Herzegovina ${ }^{18}$ (Fig. 14) has four types of the plan split level. The elevated part of the hall (divanhana) is discretely separated from the central hall and meant as a drawing or a sitting room. The rooms feature interior split levels in a form of benches for sitting or lying down (minderluk)

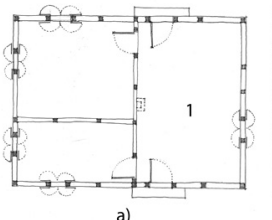

Figure 12. The Jovanović's house, Ljig area, Serbia (a. ground floor plan - (1) kuća, and b. appearance)

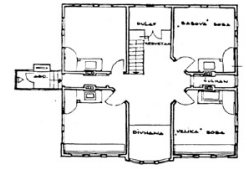

a)
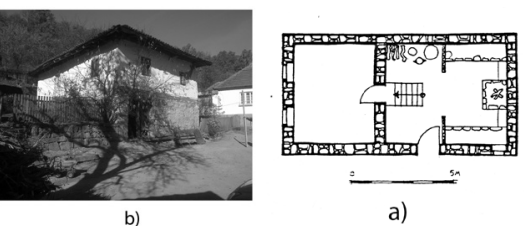

a)

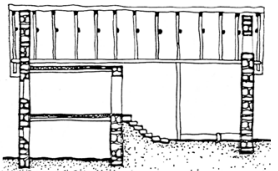

b)
Figure 13. A stone house over a cellar, Nevesinje, Bosnia and Herzegovina (a. plan and b. cross-section)
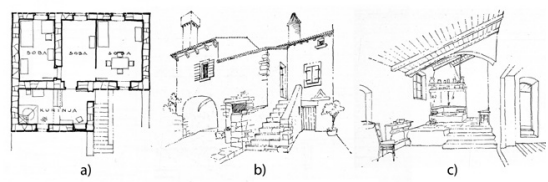

Figure 14. A bey's leisure house, Brčko area, Bosnia and Herzegovina (a. floor plan and b. appearance)

Figure 15. A house in Medulin, Istria, Croatia (a. ground floor plan, b. appearance and c. kitchen interior) 
below the windows overlooking the street. There is an interesting split level in the added, projected section of a bathroom, as well as an elevated part above the hall staircase, traditionally called a "small bed". Also on a discretely split level (right section of the plan) is a room, quite characteristic to this type of houses, where furnaces were placed, heating the rooms, locally called chulhan.

15. In the far north of the Adriatic coast, in the west borders of the Balkans, there is a stone house with a fireplace in Medulin, Croatia ${ }^{19}$ (Fig. 15). The ground plan of its elevated ground floor features a kitchen with an emphasised split level in one floor area. One section of the floor is split due to the structural reasons (below is a stone vault of a stone cellar, creating the three steps). The other split level is made for functional reasons as it is constructed to separate the fireplace from the rest of the room. It is a successful example of how technical requirements could be in accord with the quality of the spatial arrangement.

\section{THE RELATIONSHIP BETWEEN THE HORIZONTAL PLAN AND THE LAND MORPHOLOGY, THE APPLIED STRUCTURE AND SPACE PURPOSE}

The above stated examples of the horizontal split level plan in traditional houses could be classified according to the following criteria:

- The land morphology where the house is built (flat or sloping),

- Building structure (wooden architrave or stone vault) and

- The function, purpose of the space.

The horizontal split level plan takes the first two criteria as follows:

a) Direct adjustment to the rocky and sloping terrain configuration causes the ground floor to be split in two levels, following the land natural morphology ${ }^{20}$ with minimal adaptations (Figs. 1b, 3 and 6).

b) In the sloping terrain, the split level occurs due to elevating the floor level above the stone vault that in on the ground floor in the Adriatic coast house (Fig. 15) or due to creating a farming storage room on the ground floor in a stone house in Herzegovina (Fig. 13).

c) The floor split level occurs due a wooden floor separation, made of wood planks, above a partially dug out cellar (Fig. 9b).

Those split levels have no special functional or aesthetic reasons. 
However, in the majority of the given examples, the difference in the horizontal plan levels was usually made as a result of a need to distinguish certain functions (sitting, repose, hygiene, cooking, etc.), to set a particular purpose to an interior area or a part of it. The analysis of the examples showed that the functional split level, depending on the space purpose, was achieved in two ways. One involved certain interventions in the structural building, which is reflected not only in its structure but in its overall appearance (Figs. 3, 4, 5, 6, 7, 8, 10, 11 and 14). The other meant interventions within the interior, in a form of secondary split level (benches for sitting, elevated bed base, sofas, then staircases, etc.), which are not reflected in the primary structure or the house overall appearance (Figs. 2, 4, 5, 9 and 15).

\section{SPLIT LEVEL HORIZONTAL HOUSE PLAN: REASONS OF IMPLEMENTATION}

The basic goal of analysing the applied horizontal plan split level in the traditional Balkan region houses was to find out why those differences in the floor levels occurred. So, there are two general reasons for the split level horizontal house plan: the land natural configuration and the functional needs.

1. Adjustment to the land natural configuration. Motives for such adjustments are found in building optimisation, rational use of material and resources and a need for as little intervention in the natural environment as possible. It is a consequence of a highly practical, experience driven approach, but also an awareness of a traditional builder that such a way of construction enables, what we call today, sustainability and harmony with nature (Figs. 1,13 and 15).

2. Functional needs. There are several major causes deriving from an everyday life in a house model, i.e. how both the users and builders materialise their basic needs:

a. Separating and screening the fireplace - a technical and functional need (fire prevention, easy fire maintenance) to separate the area with fire or the cooking area or just sitting around the fire (Figs. 4, 5, 8 and 13). Also, we should not forget a domestic symbolic meaning of a hearth and its role in a house, which is thus emphasised with the split floor level.

b. Separating and elevating a sleeping area: a sofa in Greek islands, parts of a gallery in the Bulgarian houses, a minsofa in Macedonia and Serbia. This area is also often combined with a storage space or a staircase below (Figs. 2, 4 and 8). 
c. Emphasising certain significant parts of the interior central space, hall or an open gallery, by splitting the horizontal floor level, elevating the emphasised areas (divanhana, closed balconies and decks). It is a successful way of differentiating special function areas (Figs. 3, 4, 5, 6, 7, 8, 10, 11 and 14).

d. Creating storage space and hidden spaces using various horizontal plan levels, often combined with some other function - characteristic to Macedonia and Bulgaria (Figs. 4 and 8).

e. Split level floors in the threshold areas between the rooms, porches and galleries, which differentiates the house space but also connects it with other functional areas, a garden, an outdoor space (Fig. 8). Also, the split level floors emphasise certain functions (a bed, a crib and a place of repose) on porches and galleries. Various and multiple split levels actually make those home areas the most attractive ones in visual terms (Fig. 7).

f. Floor split levels that separate the area with water is quite characteristic to Muslim houses but is also important for the quality of living - to separate areas for washing hands, dishes, for bathing or flushing a toilet (Fig. 8, 10 and 11).

\section{CONCLUSION}

Based on the conducted analyses and considering the reasons for the split level horizontal house plan occurrence we can draw some preliminary and general conclusions:

1. The split level horizontal house plan is not directly related to the housing programme complexity. Horizontal split levels occur equally in the simplest structures (bunya, Crete) and in the very complex ones (a house in Smiljan, Bulgaria or the one in Ohrid).

2. The complexity of the horizontal plan arrangement (number of rooms, functional units and combinations) is not in a direct correlation with a number of horizontal levels splits. The examples of houses of a simple programme, e.g. a Debar house (Fig. 7) has only two rooms at one level, while the gallery in front of them has nine different horizontal level splits. We may even say that it is in those modest houses that the horizontal plan differentiation is even more necessary so as to compensate for the lack of more rooms. 
3. There are far more horizontal level splits done due to functional reasons than due to the structural ones. They, however, do feature structural splits, but it is never the other way round. The analysis of the presented examples shows that only $25 \%$ of the said structures have split levels due to the natural land configuration.

4. Functional horizontal level splits are characteristic to the "passage" zones porches, galleries and covered decks - at points of passing from the indoor and outdoor spaces (Fig. 4, 7 and 8).

5. The horizontal level splits are the most effective on the top floors, where the differentiation in the horizontal levels provide the best quality zones connecting with nature and the environment (Fig. 5, 7 and 9), but also in a ground floor house (Fig. 8), which is an exception.

6. When dimensions are considered, the difference between the levels are usually as follows:

- In simple structural splits in a form of just a step it is about $20 \mathrm{~cm}$, which a sum of a thickness of a beam and the secondary structural elements (Fig. 12), or rarely two steps of about $15 \mathrm{~cm}$ (Fig. 15).

- In the combined and complex (multiple) splits, the difference between the levels is most often the dimension according to a proportional key taken from the traditional measurement units - cubit, foot, yard, etc. (Fig. 7c).

- In the interior horizontal level splits, the difference goes to the level of a sitting position (examples of Bulgaria, Macedonia, Bosnia and Herzegovina, from $28.5 \mathrm{~cm}$ to $47.5 \mathrm{~cm}$ ), but can also go to a half body length (or even more) ${ }^{21}$, which introduces three or more unusually high steps (Fig. 2d).

7. In terms of the used materials in splitting the horizontal levels, the following has been found:

- In all the studied examples the split level, as well as the house itself, were done using the easily available materials, found in the immediate environment (Fig. 15).

- Simple split level structures were made with simple materials (wood, stone, fired or non-fired brick), as the process itself was a simple one; most often, only one material was used (Figs. 1, 12 and 15).

- In the more complex examples that feature multiple split levels, the applied material, as well as the construction process, was the same ones that were applied to the entire house (Figs. 3, 4, 5, 6, 7, 8, 10 and 11). 
8. In visual terms, the split levels are more of an arrangement of the interior than of an exterior of the house. Well-crafted horizontal floor split levels, screens, partitions, different column types, benches, ceilings and doors ${ }^{22}$, give the interior a higher, picturesque and dynamic quality, along with numerous possibilities of shaping details in an artful manner (Figs. 2d, 6c, $8 \mathrm{~b}$ and $15 \mathrm{c}$ ). The split levels visible in the exterior, on the façades, are mostly a feature of the houses built of wood, the wooden beam frame structure. Those are projections from the façade: covered balconies, small, corner covered balconies, galleries, divanhana, etc. ${ }^{23}$ The structural elements of the projections are profiled and supported with beams, braces and consoles, often especially decorated (Fig. 3b).

Finally, concluding the discussion of the split level horizontal house plan in the Balkan region vernacular architecture, we can say that the application of a split level house plan is generally quite significant in arranging the modern residential space. It is quite interesting that this element also occurs in the residential houses designed by the pioneers of modern architecture in the early 20th century: Adolf Loos, Frank Lloyd Wright, Antonio Gaudi, Charles Rennie Mackintosh ${ }^{24}$ (Fig. 16) and others. The split level floor can be applied in both simple and complex space arrangements of modern dwelling. It is particularly useful in building extensions, reconstructions and adaptations of historic buildings, as it provides possibilities of "hiding" the structural changes, modern fixtures and other equipment so that it would be invisible in the interior.

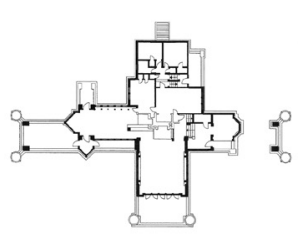

a)

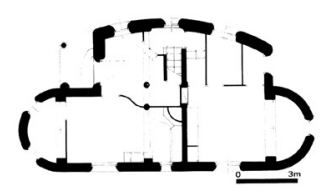

c)

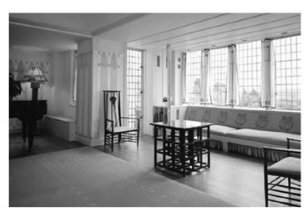

b)

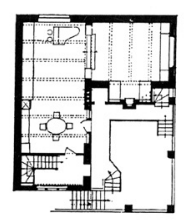

d)

Figure 16. TSplit level horizontal house plan examples in the 20th century architecture (a. F. L. Wright, Ward W. Willits House, 1901, Highland Park, Illinois, ground floor; b. C. R. Mackintosh, Hill House, 1902, a living room detail; c. A. Gaudi, Park Güell, 1914, ground plan of the office building, Barcelona; and d. A. Loos, The Moissi House, 1923, Venice, Italy, second floor) 
Tradition teaches us that various floor levels provide for shaping dynamic and picturesque ambiance of a dwelling space, emphasise and separate certain space areas, like an entrance zone (Figs. 8a and 16a), a living area (Figs. 4b,11b, 16a and 16d), an outdoor area connecting with the natural environment - terraces, porches, loggias, etc. (Figs. 5, 7 and 8). This analysis reveals a message for the future that traditional builders convey through anthropomorphic shapes and measurements and through materialisation that meets everyday life functional needs: how small changes in the horizontal floor plan levels in a residential house can open up to diverse, visually pleasant and cosy areas of a unified living space, without any partitioning or fencing. It can serve as guide for improving and refining a modern house space and for reviving this feature in the contemporary architectural practice. 
Кратка история на Българската архитектура, fig. 301, p. 277.

Dušan Grabrijan, Makedonska hiša - ali prehod iz stare orijentalske v sodobno evropsko hišo (Ljubljana: Partizanska knjiga, 1976), fig. 5, p. 36.

Марула Николоска, Градските куќи од XIX век во Македонија - просторна организација (Републички завод за заштита на спомениците на културата, 2003), fig. 283, drawing 205.

Grabrijan, Makedonska hiša - ali prehod iz stare orijentalske v sodobno evropsko hišo, fig. 47, p. 109.

Јован Крунић, Кућа и вароши у области Старе Рашке (Београд: Завет и РЗЗСК Србије, 1994), fig. 24.9 , p. 36.

Ibid, fig. 27.2 , p. 39.

Ibid, fig. 35, p. 178.

On the origin of shapes and influences of Levantine architecture, see: Мирјана РотерБлагојевић,Стамбена архитектура Београда у 19. и почетком 20 века (Београд: Архитектонски факултет универзитета у Београду, Орион арт, 2006), 154-166.

Author's personal archives: the Jovanović's house, Ljig area, photo November 2015.

Dr Muhamed Kadić, Starinska seoska kuća u Bosni i Hercegovini (Sarajevo: Veselin Masleša, 1967), fig. 60 , p. 47.

Ibid, fig. 193 and fig. 194, p. 124 and p. 125.

Aleksandar Freudenreich, Narod gradi na ogoljenom krasu (Zagreb: Savezni institut za zaštitu spomenika kulture, 1982), fig. 246 and fig. 503, p. 110 and 172.

See: Kadić, Starinska seoska kuća u Bosni i Hercegovini, fig. 127, p. 82.

Ђорђе Петровић, Неимарска правила и ариин, Београд: Докторске универзитезске дисертације, едиција часописа „Универзитет данас“, 1973, fig. 15, p. 33.

See interior examples in: $\triangle \mathrm{HМНТРН \Sigma} \mathrm{ФІАІППІ \triangle Н \Sigma} \mathrm{(Eds.),} \mathrm{E \Lambda \Lambda HNIKH} \mathrm{ПAPA \triangle O \Sigma IAKH}$

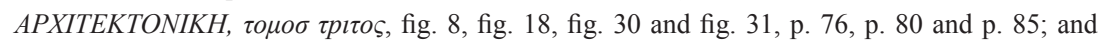

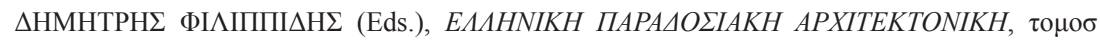
$\varepsilon \kappa \tau о \sigma$, p. 53 , p. 50.

Александар Дероко, Народно неимарство, Београд: I и II, Споменик САНУ, CXVIII, Одељење друштвених наука, нова серија, 20, 1968, fig. 18, fig. 20 and fig. 103-106, p. 42, p. 57 and p. 167.

See: A. Loos, Villa Moisi, Venice, in: Raumplan versus plan libre (Rotterdam: 2008), 101; F. L. Rajt, Kuća Vorda V.Vilitsa in: Brus Bruks Fajfer, Frenk Lojd Rajt 1867-1959. (Beograd: Taschen/ IPS, 2005), 21; A. Gaudi, Two pavillions at the entrance to Park Güell; in Zerbst, Rainer. Antoni Gaudi (Taschen, 1985), 143; C. R. Mekintoš, Kuća Hil, Glazgov, in: Christian Norberg Schulz, Stanovanje-stanište, urbani prostor, kuća (Beograd: Gradjevinska knjiga, 1990), 92. 
Fajfer, Brus Bruks. Frenk Lojd Rajt 1867-1959. Beograd: Taschen/IPS, 2005.

Цвијић, Јован. Балканско полуострво и јужнословенске земье, III, Београд: 1922.

Дероко, Александар. Народно неимарство: I и II, Београд: Споменик САНУ, CXVIII, Одељење друштвених наука, нова серија, 20, 1968.

ФI IIППІ $\triangle \mathrm{H} \Sigma \triangle \mathrm{HMHTPH \Sigma} \mathrm{(Eds.)} \mathrm{E \Lambda AHNIKH} \mathrm{ПАPA \triangle O \Sigma IAKH} \mathrm{APXITEKTONIKH,} \mathrm{\tau о \mu о \sigma} \mathrm{\varepsilon к \tau о \sigma ,}$ $\Theta E \Sigma \Sigma A \Lambda I A-H \Pi E I P O \Sigma, \mathrm{ME} \Lambda \mathrm{I} \Sigma \Sigma \mathrm{A}, 1988$.

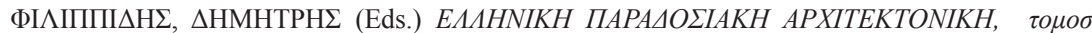

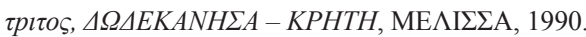

Freudenreich, Aleksandar. Narod gradi na ogoljenom krasu, Zagreb: Savezni institut za zaštitu spomenika kulture, 1982.

Grabrijan, Dušan. Makedonska hiša - ali prehod iz stare orijentalske v sodobno evropsko hišo. Ljubljana: Partizanska knjiga, 1976.

Kadić, Dr Muhamed. Starinska seoska kuća u Bosni i Hercegovini, Sarajevo: Veselin Masleša,1967. Којић, Бранислав. Стара градска и сеоска архитектура у Србији. Београд: Просвета, 1949.

Кратка история на Българската архитектура. София: Българска академия на науките, 1965.

Крунић, Јован. Кућа и вароши у области Старе Рашке. Београд: Завет и Републички завод за заштиту споменика културе Србије, 1994.

Ненадовић, Слободан М. Илустровани речник израза у народној архитектури, Београд: Просвета, 2002.

Николоска, Марула. Градските куќи од хіх век во Македонија - просторна организаиија. Скопје: Републички завод за заштита на спомениците на културата, 2003.

Norberg Schulz, Christian. Stanovanje-stanište,urbani prostor, kuća, Beograd: Gradjevinska knjiga, 1990.

Обрадовић, Тихомир. Прелазнипросториутрадиционалномградитељству, специјалистички рад, Београд: Универзитет у Београду - Архитектонски факултет, 1995.

Обрадовић, Тихомир. Типолошка анализа прелазних простора, магистарски рад, Београд: Универзитет у Београду - Архитектонски факултет, 2000.

Павловић, Доброслав Ст.; Ангелова, Рахела; Мицопулос, Никола; Стојка, Жоржет; Халук, Сезгин. Народно градитељьтво на Балкану. Београд: РЗЗСКС, САНУ, ДКС, 1987.

Петровић, Ђорђе. Неимарска правила и ариин. Београд: Докторске универзитетске дисертације, едиција часописа „Универзитет данас“, 1973.

Risselada, Max (Ed.). Raumplan versus plan libre, Adolf Loos/Le Corbusier. Rotterdam: 010 Publishers, 2008.

Ротер-Благојевић, Мирјана. Стамбена архитектура Београда у 19. и почетком 20.века. Београд: Архитектонски факултет универзитета у Београду, Орион Арт, 2006.

Волињец, Радомир; Хаџиева-Алексиевска, Јасмина. Функционално обликовна концепција во архитектурата на старата тетовска куќа. Скопје: Универзитет Кирил и Методиј, 1983.

Zerbst, Rainer. Antoni Gaudi, Taschen, 1985. 